EGU21-13154, updated on 18 Aug 2021

https://doi.org/10.5194/egusphere-egu21-13154

EGU General Assembly 2021

(c) Author(s) 2021. This work is distributed under

the Creative Commons Attribution 4.0 License.

\title{
Origin and significance of the antimony mineralisation associated to mafic intrusions in the Iberian Zone and the Central Armorican Domain
}

Eric Gloaguen ${ }^{1}$, Héctor Campos ${ }^{1}$, Anthony Pochon ${ }^{1}$, Pablo León Higueras ${ }^{2}$, Saturnino Lorenzo ${ }^{2}$, José-María Esbrí ${ }^{2}$, Giada lacono-Marziano ${ }^{1}$, and Alexandre Lima ${ }^{3}$

${ }^{1}$ Université d'Orléans/CNRS/BRGM/ISTO, UMR 7327, F-45071 Orléans, France

${ }^{2}$ Instituto de Geología Aplicada \& Departamento de Ingeniería Geológica y Minera. E.I.M.I. Almadén, Universidad de CastillaLa Mancha, Plaza Manuel Meca 1, E-13400 Almadén (Ciudad Real), Spain

${ }^{3} \mathrm{ICT}$ - Polo do Porto, Departamento Geociências, Ambiente e Ordenamento do Território, Faculdade de Ciências,

Universidade do Porto, Portugal

In the Central Iberian Zone (CIZ) and its French counterpart, the Central Armorican Domain (CAD), widespread swarms of mafic dykes with various ages and compositions are known. Indeed, numerous mafic events are recognized in the late Neoproterozoic, in the Cambrian to the Ordovician, in the Ordovician to the Devonian, at the Devonian-Carboniferous boundary, in the Permian and in the Jurassic. Such a succession of mantle partial melting events, localised or generalized, may have strong consequences (i) on the composition and the homogeneity of the mantle below both the $\mathrm{CIZ}$ and CAD, and (ii) on the transfert of metals in the overlying crust. Moreover, the mantle below these domains must have been modified also by the subduction of large to small oceanic crusts from the lapetus, the Rheic, the Galicia-Moldanubian and the Paleotethys. Although the occurrences of paleo-subductions below the $\mathrm{CIZ}$ and CAD remain discussed, the southern border of the $\mathrm{CIZ}$, the Ossa-Morena Zone (OMZ), is considered as a suture zone resulting from a subduction followed by a collision between 390 and $360 \mathrm{Ma}$ (D1), according to the 2 opposite structural vergences at the CIZ/OMZ boundary, as well as the location of a NE-dipping slab imaged by seismic profiles. In the Armorican massif, the end of subduction is also dated at $360 \mathrm{Ma}$ and associated to a north-directed subduction. The trace of this subduction below the CAD is visible in the tomographic dataset. Interestingly, these two domains (CIZ and CAD) contain the largest number of Palaeozoic antimony deposits, antimony being a volatile element. In these domains, the large clustering of antimony deposits and occurrences is observed within a ca $100 \mathrm{~km}$ wide bands along their southern parts. In the two domains, the antimony deposits are frequently spatially associated with diabase dykes. Diabase dykes and associated antimony mineralisation have been dated at $360 \mathrm{Ma}$ in the CAD but remain temporally unconstrained in the $\mathrm{CIZ}$. Nevertheless, since these dykes are strongly affected by the Variscan deformation a minimum age of $350 \mathrm{Ma}$ is inferred. Both, the peculiar composition of these diabase dykes, relatively enriched in $\mathrm{Cs}, \mathrm{Li}, \mathrm{Pb}$ and relatively depleted in $\mathrm{K}$ and $\mathrm{Rb}$, the spatial association with antimony at the end of a $360 \mathrm{Ma}$ subduction, suggest a link between antimony and a ca 360Ma mafic magmatism which could result from the partial melting of a subduction-related metasomatized mantle. 
This work was funded by the ANR (ANR-19-MIN2-0002), the AEI (MICIU/AEI/REF.: PCI2019-103779), the FCT (ERA-MIN/0005/2018) and author's institutions in the framework of the ERA-MIN2 AUREOLE project (https://aureole.brgm.fr). 